\title{
Effective Role of Multiple Electrodes on Double Chambered Microbial Fuel Cell
}

\author{
Geetha.$S^{1}$, Subha Ranjani . $\mathbf{S}^{2}$ \\ ${ }^{1}$ M.Sc Microbiology, Department of Microbiology, The Standard fireworks Rajaratnam College for women, Sivakasi \\ ${ }^{2}$ Assistant professor, Department of Microbiology, The Standard fireworks Rajaratnam College for women, Sivakasi
}

\begin{abstract}
The main goal of this current project was to overcome the problems of energy management which is the global issue today. In our current study the electricity was produced by using the industrial wastewater as a substrate so simultaneously the water management and the electricity also produced by this method. This study is concentrated on the comparison of electricity generation by two different organic substrates like the mixture of whey and rotten tomato juice and Rice washing water electricity generation with Saccharomyces cerevisiae, and Escherichia coli and also the comparative study on various combinations and number of electrodes also plays an important role in the microbial fuel cells. Microorganisms were able to utilize the carbon source in the substrate for generation of bioelectricity. Microbial fuel cell act as biocatalyst and generates electrons (e-) and protons $\left(H_{+}^{+}\right)$by way of anaerobic respiration of organic substrate. The electron transfer through the anode integrated with an external circuit to cathode and protons diffuse through the Agar salt bridge. The open circuit potential was determined and the maximum voltage given by different organisms was estimated.
\end{abstract}

Keywords: Microbial Fuel Cell, electrode, Saccharomyces cerevisiae, E. coli, open circuit potential

\section{Introduction}

In recent days, a number of methods and sources are currently in use for production of electrical energy which includes hydro-power, solar power, wind power, wave power, batteries, fossil fuels and chemical fuel cells. All these technologies play a significant role in the global issue of energy management. In addition to these technologies an attractive and novel alternative new technology to produce electricity from renewable resources without a net Carbon dioxide emission is much desired[1],[2]. All over the world, biomass-to-electricity generation has benefits. Bioelectricity is a new term in the field of bio-energy. The future electricity generation will be certainly included with the most promising systems, which must have great attention by virtue of their inherently ultra-clean, efficient, and reliable performance.

Microbial fuel cell (MFC) technology is a prospective technology that purifies wastewater and converts its chemical energy into electrical energy using microorganisms as biocatalysts [3]. MFCs are one of the renewable sources of energy for the production of electricity from waste. A microbial fuel cell is a device that converts chemical energy to electrical energy by the catalytic reaction of microorganisms [4]. In addition, the MFCs offer an environmentally friendly alternative to fossil fuels [1].The disintegration of organic compounds by microorganisms is accompanied by the liberation of electrical energy [5],[6]. These fuel cells are based on metabolic activity of microorganisms on the organic substrates which contains sugars as the main component.

Micro-organisms need energy to survive, in the same way as humans need food to live. Micro-organisms get this energy in a two-step process. The first step requires the removal of electrons from some source of organic matter (oxidation), and the second step consists of giving those electrons to something that will accept them (reduction), such as oxygen or nitrate. When micro-organisms consume a substance such as sugar in aerobic conditions, they produce Carbon dioxide and water. However, when oxygen is not present, they produce Carbon dioxide, protons, and electrons,

$$
\mathrm{C}_{12} \mathrm{H}_{22} \mathrm{O}_{11}+13 \mathrm{H}_{2} \mathrm{O} \rightarrow 12 \mathrm{CO}_{2}+48 \mathrm{H}^{+}+48 \mathrm{e}^{-}
$$

The electrons then move across a wire under a load (resistor) to the cathode where they combine with protons and oxygen to form water. When these electrons flow from the anode to the cathode, they generate the current and voltage to make electricity.

Various research groups are keenly interested to improve the current density by more facile and efficient methods[7],[8], [9],[10]. Generation of electrical energy is based on the principles of fermentation in which organic substrate undergo the biochemical reaction in the presence of microorganisms which result in the formation of the hydrogen fuel. The fuel so formed is finally converted into electrical energy [11].

Basically there are two types of MFC, First Mediator microbial fuel cell -Most of the microbial cells are electrochemically inactive. The electron transfer from microbial cells to the electrode is facilitated by mediators such as thionine, methyl viologen, methyl blue, humic acid, neutral red and so on ${ }^{[4,6]}$. Most of the mediators available are expensive and toxic. The ideal mediator has the following properties: i) It should display reversible redox reaction to function as an electron shuttle; ii) It should have appreciable solubility in an aqueous solution and stability; iii) It should freely penetrate the cell membrane to capture electrons; and iv) It should have low formal potential. The lower the formal potential, the larger the cell voltage since it is the difference between the cathode and anode potentials. Second Mediator-free microbial fuel cell do not require a mediator but uses electrochemically active bacteria to transfer electrons to the electrode (electrons are carried directly from the bacterial respiratory enzyme to the electrode). An 


\section{International Journal of Science and Research (IJSR) \\ ISSN (Online): 2319-7064 \\ Index Copernicus Value (2015): 78.96 | Impact Factor (2015): 6.391}

attempt has been made in our laboratory to generate electricity using mediator less Microbial Fuel Cell.

Presently, research on MFCs using wastewater as substrate is in the initial stages of laboratory evaluation around the world. The reported work so far is mainly based on using the monoculture at laboratory level [12],[13],[14]. The use of energy is increasing day by day. Thus there is a need to search for alternatives to fossil fuel, utilizing renewable energy from waste organic source is the present trend of active research and in view of this bioelectricity generation through microbial fuel cell using variety of substrate is being studied extensively. It is well known that microorganisms can produce fuels from organic matters. The main objective of this work was to utilize waste water and waste products rich in ions or organic content which can be used as a potent source to generate electricity using Escherichia coli as inoculum to design microbial fuel cells employing low-cost materials without using toxic mediators, From this work waste can be used to generate electricity at the same time reduce the damage done to the natural environment.

\section{Materials and Methods}

\subsection{MFC Construction}

All experiment was conducted using a two chambered MFC consisting of two glass bottles $(3000 \mathrm{ml}$ capacity). The agar salt bridge was used instead of proton exchange membrane (PEM). The salt bridge was used for the electrolytic contact of the solutions in the two bottles, where the two electrodes of the MFC were immersed. The anode and the cathode electrodes were made of different electrode materials. The anode compartment was filled with substrate and inoculum and anaerobic condition was maintained. The cathode compartment was filled with distilled water and it was continuously aerated to maintain aerobic condition. The electrodes were connected with Copper wire to a digital multi meter.

\subsection{Preparation of Salt Bridge}

The salt bridge was prepared by making 5-7\% agar in $\mathrm{KCl}$ solution filled inside the PVC pipe to be used as separator in the MFC system. At first $\mathrm{KCl}$ solution was prepared by dissolving $7.45 \mathrm{gm} \mathrm{KCl}$ in $100 \mathrm{ml}$ of Double Distilled Water (DDW) and then used this solvent to make 5-7\% agar. The solvent was heated and simultaneously the agar powder was added gradually until a clear homogeneous suspension was obtained. Molten agar was poured into the PVC pipe having length of $35 \mathrm{~cm}$, width of $25 \mathrm{~cm}$ and Internal Diameter of 20 $\mathrm{mm}$. The tube was sealed from both ends, once the agar gets solidified on cooling, the seals were removed. This was used as the salt bridge in the MFC system.

\subsection{Preparation of Substrate}

\subsubsection{Whey Water}

Paneer whey is the lactose-rich watery by product of paneer manufacturing .Paneer whey was obtained from local Dairy industry. The initial $\mathrm{pH}$ of the whey was 5.5. The solution was autoclaved at $121^{\circ} \mathrm{C}$ for $15 \mathrm{~min}$, then cooled down to room temperature, centrifuged at $11,000 \mathrm{x} \mathrm{g}$ in sterilized tubes for 15 minutes to remove aggregated solids. The supernatant (whey supernatant), was taken and it was used after adjusting $\mathrm{pH}$ to 7 by the $\mathrm{NaOH}$ solution $(1 \mathrm{M})$, as the major constituent of media for the growth of microorganisms. The treated whey was used as Carbon source and the whey's carbohydrate was considered as lactose.

\subsubsection{Rotten Tomato Juice}

Rotten tomatoes were collected from local vegetable market. Tomato juice was prepared and the initial $\mathrm{pH}$ of the tomato juice was checked. The juice was autoclaved at $121^{\circ} \mathrm{C}$ for 30 min, then cooled down to room temperature. The treated rotten tomato juice was used as a substrate.

\subsubsection{Mixture of Whey Water and Rotten Tomato Juice: (RTJ\&WW)}

Pre treated whey water and rotten tomato juice was taken in the ratio of 1:1 and mixed well. The mixture was used as a substrate.

\subsubsection{Rice washed water: (RWW)}

Rice was purchased from local market in Sivakasi and was soaked in water for 1 hour. This rice washed water was filtered and the $\mathrm{pH}$ of the filtrate was checked and adjusted to 7.This filtrate was used as a substrate for MFC.

\subsection{Inoculam preparation}

Many microorganisms possess the ability to transfer the electrons derived from the metabolism of organic matters to the anode. In our study we used Saccharomyces cerevisiae and Escherichia coli.

\subsubsection{Saccharomyces cerevisiae:}

Saccharomyces cerevisiae was purchased from the local super market in sivakasi. $5 \mathrm{~g}$ of Saccharomyces cerevisiae was employed in an anaerobic jar. This is act as biocatalyst.

\subsubsection{Preparation of Escherichia coli culture:}

Escherichia coli were revived in $50 \mathrm{ml}$ nutrient broth and incubated at $37^{\circ} \mathrm{C}$ for 24 hours. $5 \mathrm{ml}$ of this culture was inoculated in the substrate.

\subsection{Studies on electrode materials}

There are different types of electrode materials used for increasing the efficiency of the MFC. The Type of material used in electrode preparation will shows vital effect on MFCs efficiency. The different electrodes used in our study are Copper $(\mathrm{Cu})$, Carbon $(\mathrm{C})$ and Graphite $(\mathrm{Gr})$. Copper electrodes were $14 \mathrm{~cm}$ long and $0.1 \mathrm{~cm}$ in diameter. The dimension of Carbon electrodes was $12 \mathrm{~cm} \mathrm{x} 1.5 \mathrm{~cm}$ and the Graphite electrodes were $20 \mathrm{~cm}$ long and $0.3 \mathrm{~cm}$ in diameter. The combinations of anode and cathode materials are tabulated in table: 1

Table 1: Different combination of anode and cathode electrodes

\begin{tabular}{|c|c|}
\hline ANODE & CATHODE \\
\hline Graphite $(\mathrm{Gr})$ & Copper $(\mathrm{Cu})$ \\
\hline Carbon $(\mathrm{C})$ & Copper $(\mathrm{Cu})$ \\
\hline
\end{tabular}

\section{Volume 6 Issue 1, January 2017




\section{International Journal of Science and Research (IJSR) \\ ISSN (Online): 2319-7064}

Index Copernicus Value (2015): 78.96 | Impact Factor (2015): 6.391

\subsection{List of Double Chambered MFC Setups}

About 16 MFC setups were made by using the combinations of electrodes and the substrates mentioned previously. A list of MFCs are shown in Table 2. Together with their substrates, various combinations of electrodes and number of electrodes used in MFCs also tabulate.

Table 2

\begin{tabular}{|c|c|c|c|c|}
\hline Substrate & Culture & Anode & Cathode & No of electrodes \\
\hline RWW & \multirow[t]{2}{*}{ Yeast } & \multirow[t]{2}{*}{ Gr } & \multirow[t]{2}{*}{$\mathrm{Cu}$} & \multirow[t]{2}{*}{1} \\
\hline RTJ\&WW & & & & \\
\hline RWW & \multirow[t]{2}{*}{ Yeast } & \multirow[t]{2}{*}{$\mathrm{C}$} & \multirow[t]{2}{*}{$\mathrm{Cu}$} & \multirow[t]{2}{*}{1} \\
\hline RTJ\&WW & & & & \\
\hline RWW & \multirow[t]{2}{*}{ E.coli } & \multirow[t]{2}{*}{ Gr } & \multirow[t]{2}{*}{$\mathrm{Cu}$} & \multirow[t]{2}{*}{1} \\
\hline RTJ\&WW & & & & \\
\hline RWW & \multirow[t]{2}{*}{ E.coli } & \multirow[t]{2}{*}{$\mathrm{C}$} & \multirow[t]{2}{*}{$\mathrm{Cu}$} & \multirow[t]{2}{*}{1} \\
\hline RTJ\&WW & & & & \\
\hline RWW & \multirow[t]{2}{*}{ Yeast } & \multirow[t]{2}{*}{$\mathrm{Gr}$} & \multirow[t]{2}{*}{$\mathrm{Cu}$} & \multirow[t]{2}{*}{4} \\
\hline RTJ\&WW & & & & \\
\hline RWW & \multirow[t]{2}{*}{ Yeast } & \multirow[t]{2}{*}{$\mathrm{C}$} & \multirow[t]{2}{*}{$\mathrm{Cu}$} & \multirow[t]{2}{*}{4} \\
\hline RTJ\&WW & & & & \\
\hline RWW & \multirow[t]{2}{*}{ E.coli } & \multirow[t]{2}{*}{$\mathrm{Gr}$} & \multirow[t]{2}{*}{$\mathrm{Cu}$} & \multirow[t]{2}{*}{4} \\
\hline RTJ\&WW & & & & \\
\hline RWW & \multirow[t]{2}{*}{ E.coli } & \multirow[t]{2}{*}{$\mathrm{C}$} & \multirow[t]{2}{*}{$\mathrm{Cu}$} & \multirow[t]{2}{*}{4} \\
\hline RTJ\&WW & & & & \\
\hline
\end{tabular}

\section{Result}

The fabricated MFC was used for power generation. Mixture of whey and tomato juice, rice washing water was act as Carbon source in MFC. The abundant and cheap feed source of chemical energy was used for the purpose of electricity production. The fast growing microorganism was implemented for power generation. There was a definite increase in the voltage up to the stationary phase then voltage has been decreased due to the lactose depletion.

The entire experiments were classified by the combination of electrodes and substrates. The voltage generation was recorded per day throughout one to two week. This study proved the workability of a novel MFC design in terms of current generation. Furthermore current yield could be enhanced with different anodes sharing a common cathode, simultaneously providing possibility of serial connectivity for increasing voltage output.

\subsection{Experiment with saccharomyces cerevisiae:}

The $S$. cerevisiae culture was added into anode chamber to start up the process. Substrates were fed to all the microbial fuel cells. The output result in the form of open circuit voltage (OCV) was recorded by the Digital multimeter. Biochemical activities of the microorganisms gradually increased the electricity generation. The following figures 1 and 2 represent the comparison of electricity production by various substrates using single electrodes and multiple electrodes in a same substrate for the increased electricity production.
3.1.1. Comparison of power generation from Rice washed water and mixture of RTJ \&WW by single and multiple Carbon-Copper electrode:

In Single Carbon- Copper electrode Mixture of whey water and rotten tomato juice produced maximum voltage of 471 $\mathrm{mV}$ at $5^{\text {th }}$ day incubation, Rice Washing Water produced highest voltage of $199 \mathrm{mV}$ at $5^{\text {th }}$ day of incubation. In multiple Carbon - Copper electrode mixture of whey water and rotten tomato juice produced maximum voltage of 568 $\mathrm{mV}$ at $3^{\text {rd }}$ of day incubation, Rice Washing Water produced highest voltage of $505 \mathrm{mV}$ at $4^{\text {th }}$ day of incubation.(Figure:1)

\subsubsection{Comparison of power generation from Rice} washed water and mixture of RTJ \&WW by single and multiple Graphite-Copper electrode

In single Graphite - Copper electrode mixture of whey water and rotten tomato juice produced maximum voltage of 521 $\mathrm{mV}$ at $5^{\text {th }}$ day incubation, Rice Washing Water produced highest voltage of $398 \mathrm{mV}$ at $5^{\text {th }}$ day of incubation.In Multiple Graphite - Copper electrode mixture of whey water and rotten tomato juice produced maximum voltage of $539 \mathrm{mV}$ at 24 hours of incubation, Rice Washing Water produced highest voltage of $582 \mathrm{mV}$ at 72 hours of incubation.(Figure 2)

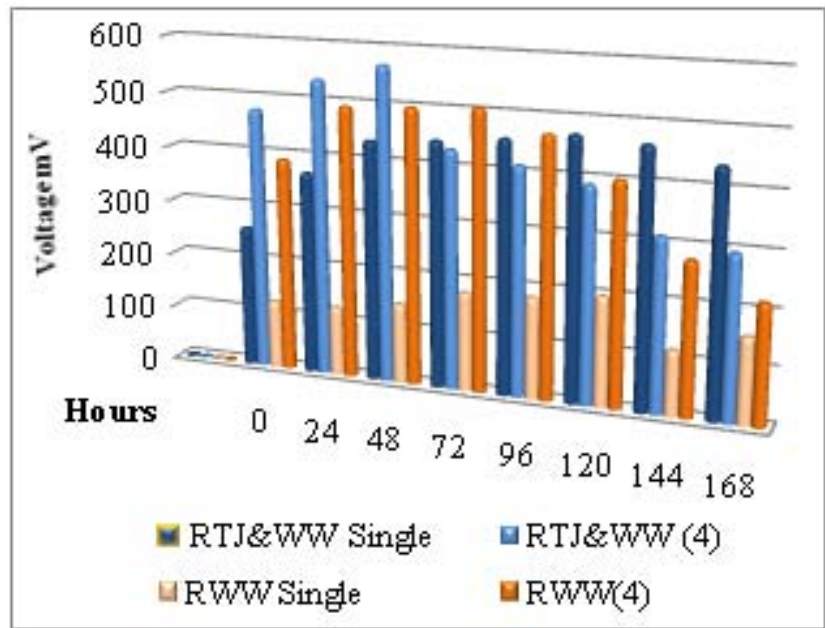

Figure 1: Diagram showing voltage generated by single and multiple Carbon-Copper electrode .

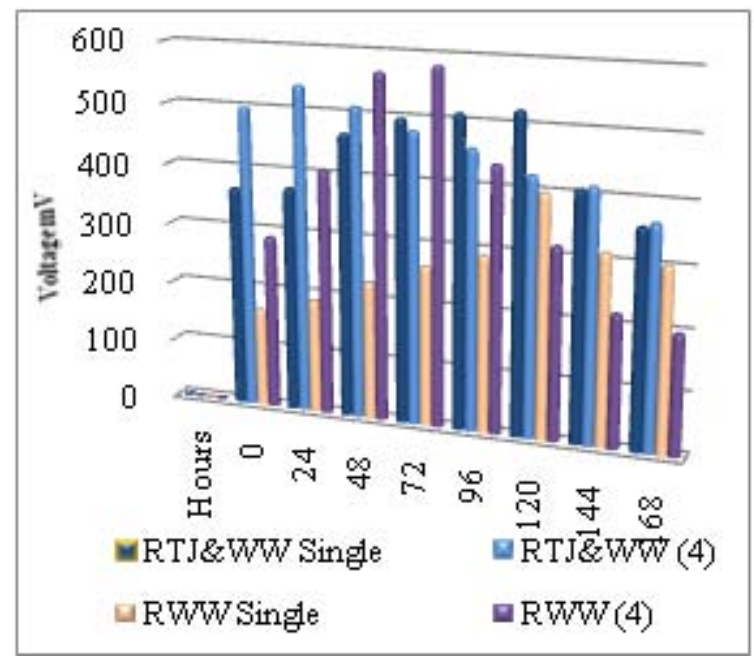

Figure 2: Diagram showing voltage generated by single and multiple Graphite-Copper electrode 


\section{International Journal of Science and Research (IJSR) \\ ISSN (Online): 2319-7064}

Index Copernicus Value (2015): 78.96 | Impact Factor (2015): 6.391

\subsection{Experiments with Escherichia coli}

The low-cost feed source was used for power production. Initially, the voltage produced by E.coli was less and then the voltage was gradually increased. At this stage, Carbon sources are utilized and products are formed. After $2^{\text {nd }}$ or $3^{\text {rd }}$ day of operation, Open-circuit voltage $(\mathrm{OCV})$ reached to a maximum value $(\mathrm{mV})$. The OCV was completely stable for more than 24 hours. Finally, rapid utilization of substrate and accumulation of products may lead to stationary phase where the cell density and voltage remains constant. After this phase cells may start to die as the cell growth rate balances the death rate. It is well known that the biocatalytic activities of the cell gradually decrease as they age. In other words, the instability was a result of lactose depletion in the anode compartment. Figure 3 and 4 represent the comparison of electricity production by various substrates using single electrodes and multiple electrodes in a same substrate for the increased electricity production

\subsubsection{Comparison of power generation from Rice washed water and mixture of RTJ \&WW by single and multiple Carbon-Copper electrodes:}

In Single Carbon- Copper electrode mixture of whey water and rotten tomato juice produced maximum voltage of 471 $\mathrm{mV}$ at $5^{\text {th }}$ day incubation; Rice Washing Water produced highest voltage of $456 \mathrm{mV}$ at $5^{\text {th }}$ day of incubation. In multiple Carbon- Copper electrode mixture of whey water and rotten tomato juice produced maximum voltage of 411 $\mathrm{mV}$ at $3^{\text {rd }}$ day incubation, Rice Washing Water produced highest voltage of $852 \mathrm{mV}$ at $2^{\text {nd }}$ day of incubation.(Figure:3)

\subsubsection{Comparison of power generation from Rice washed water and mixture of RTJ \&WW by single and multiple Graphite-Copper electrode}

In Single Graphite -Copper electrode mixture of whey water and rotten tomato juice produced maximum voltage of 464 $\mathrm{mV}$ at $5^{\text {th }}$ day incubation, Rice Washing Water produced highest voltage of $465 \mathrm{mV}$ at $4^{\text {th }}$ day of incubation. In multiple Graphite - Copper electrode mixture of whey water and rotten tomato juice produced maximum voltage of 750 $\mathrm{mV}$ at $4^{\text {th }}$ day incubation, Rice Washing Water produced highest voltage of $980 \mathrm{mV}$ at $5^{\text {th }}$ day of incubation.(Figure:4)

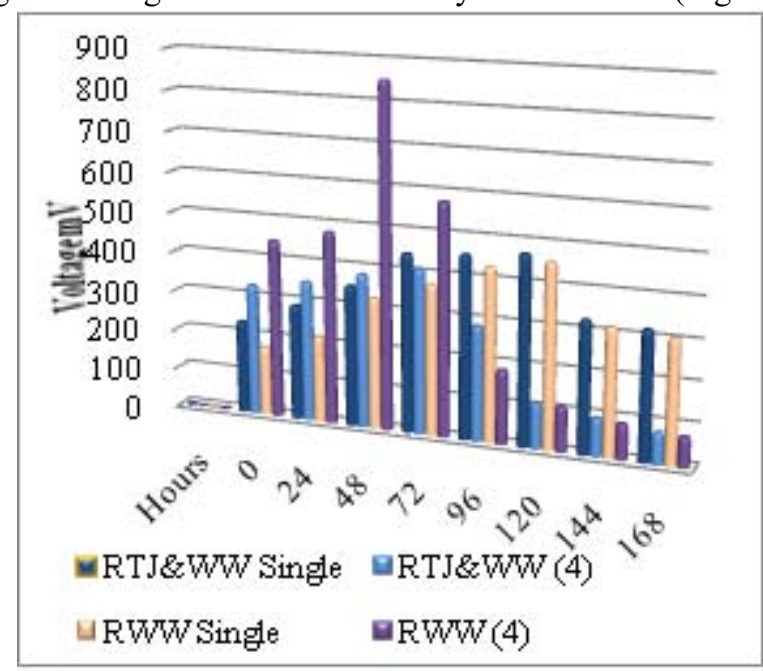

Figure 3: Diagram showing voltage generated by single and multiple Carbon-Copper electrode

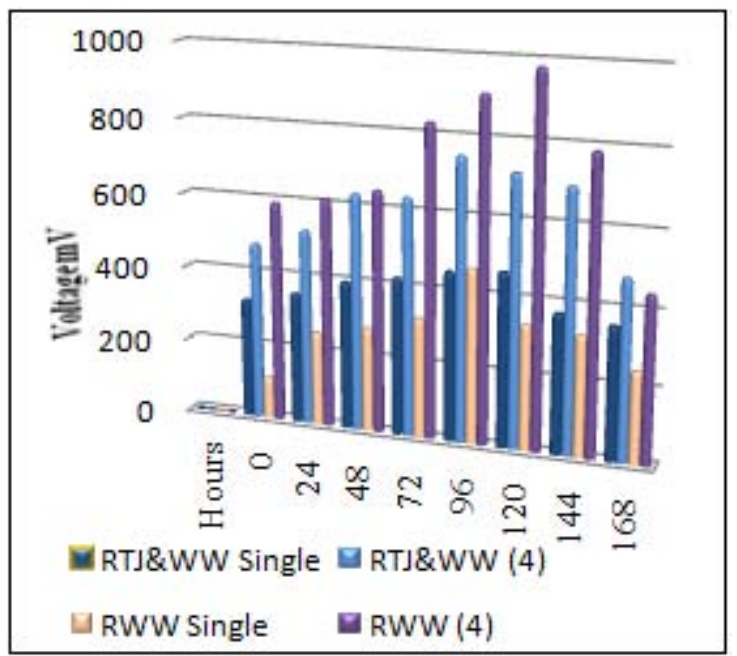

Figure 4: Diagram showing voltage generated by single and multiple Graphite-Copper electrode

\section{Discussion}

Bio electricity is generated using mediator-less Microbial fuel cell utilizing effluents from dairy and sugar industries which are rich in organic substrates as well as microorganisms. The maximum voltage from diary and sugar industry effluents measured. The maximum voltage was $450 \mathrm{mV}$, and $400 \mathrm{mV}$ respectively for a period of twenty one days. The observed results would form a basis for harnessing energy from industrial effluents and sustainable production of bioelectricity [15]. In our present study we used rice washing water, and mixture of whey water and rotten tomato juice as substrates. The maximum voltage of these four substrates was $980 \mathrm{mV}$ and $750 \mathrm{mV}$ respectively within one week.

The performance of the various combinations of electrodes which plays an important role in the microbial fuel cells for the generation of electricity was studied by Hadagali Ashoka experimented with selection of the electrodes for the best performance of a microbial fuel cell. The various combinations of anode/cathode materials like copper, zinc, aluminum, carbon, stainless steel, mild steel for MFCs has been systematically studied and out of which $\mathrm{Cu} / \mathrm{Zn}, \mathrm{Al} / \mathrm{SS}$, $\mathrm{C} / \mathrm{C}$ and $\mathrm{SS} / \mathrm{SS}$ gave higher voltage output [16]. In the same way various combinations of electrodes were used in our study such as Graphite-Copper, Carbon-Copper electrodes. Graphite-Copper electrode was found to be best compared to other electrode combinations because it maintains constant voltage for consecutive days where as other electrode combinations such as Carbon-Copper, even though producing high voltage it decreases rapidly on consecutive days.

\section{References}

[1] Lovley D.R .2006. Microbial fuel cells: novel microbial physiologies and engineering approaches. Curr Opin Biotech 17: 327-32.

[2] Davis, F and Higson, 2007. Biofuel cells-recent advances and applications. Biosens Bioelectron 22:1224-35. 
[3] Logan, B.E., B. Hamelers, R.A. Rozendal, U. Schrorder , J. Keller, S.Freguia, P. Aelterman , W. Verstraete, K. Rabaey, 2006. Microbial fuel cells: methodology and technology. Environ. Sci. Technol. 40: 5181-5192.

[4] Allen, R.M and H.P. Bennetto. 1993 Microbial fuelcells: electricity production from carbohydrates. Appl Biochem Biotech 39(40):27-40.

[5] Potter, M.C., 1910. On the Difference of Potential Due to the Vital Activity of Microorganisms, Proc. Univ. Durham Phil. Soc., 3: 245- 249.

[6] Potter, M.C., 1911. Electrical Effects Accompanying the Decomposition of Organic Compounds. Proc. $R$. Soc. Lond 84: 260-276.

[7] Palmore, G.T.R. and G.M. Whitesides, 1994. Microbial and Enzymatic Biofuel Cells" in Enzymatic Conversion of Biomass of Fuels Production", Himmel, M.E. Baker, J.O. and R.P. Overend (Eds.) ACS Symposium Series No. 566. American chemical Society. Washington : 271-290.

[8] Angenent, L.T., K. karim, M.H. Al-Dahhan, B.A. Wrenn and R. Domiguez- Espinosa,2004. Production of Bioenergy and Biochemical's from industrial and Agricultural Wastewater, Trends Biotechnol 22:477484.

[9] Bond, D.R., D.E. Holmes, L.M. Tender and D.R. Lovely, 2002. Electrode-reduction Microorganisms that Harvest Energy from Marine Sediments, science 295:483-485.

[10] Pham, H.T., J.K. Jang, I.S. Chang and B.H. Kim,2004. Improvement of Cathode Reaction of a Mediator less Microbial Fuel Cell. J. Microbiol. Biotechnol 14: 324329.

[11] Abdul Majeed Khan., 2009. Electricity Generation by Microbial Fuel Cells. Adv. In Nat. Appl. Sci 3(2): 279286.

[12]Larminie, J. and Dicks, A., Fuel Cell Systems Explained, John Wiley, UK, 2003.

[13]Park, D.H. and Zeikus, G. 2003. Improved Fuel cell and electrode designs for producing electricity from microbial degradation. Biotechnol. Bioeng, 81: 348-355.

[14] Rabaey, K., Lissens, G., Siciliano, S.D. and Verstraete, W. 2003. A microbial fuel cell capable of converting glucose to electricity at high rate and efficiency. Biotechnol. Lett. 25: 1531-1535.

[15] Ganesan Vijayan Sivaa, Rajaram Prashanthia, and Natarajan Mohanb 2014. Bio-electricity production from industrial effluents using mediator less microbial fuel cell (MFC) Journal of Environmental and Applied Bioresearch . 2: $44-48$.

[16] Hadagali Ashoka, R.Shalini and Pratima Bhat 2012. Comparative Studies On Electrodes For The Construction Of Microbial Fuel Cell. International Journal of AdvancedBiotechnology and Research 3: 785 $-789$ 